[Regular Paper]

\title{
Estimation of Critical Temperature, Critical Pressure, and Normal Boiling Point of Organic Oxygen Compounds
}

\author{
Toshihiko HIAKI ${ }^{\dagger 1) *}$ and Seiji TAKAMORI ${ }^{\dagger 2)}$ \\ †1) Dept. of Industrial Chemistry, College of Industrial Technology, Nihon University, \\ 1-2-1 Izumi-cho, Narashino, Chiba 275 \\ †2) Research Center for Advanced Technologies, The Japan Steel Works, Ltd. \\ 1-3 Takanodai, Yotsukaido, Chiba 284
}

(Received May 20, 1991)

\begin{abstract}
A method for estimating critical temperature, critical pressure, and normal boiling point of organic compounds containing oxygen has been developed using molecular weight and structure exclusively. With the proposed method, these properties of alcohols, ethers, carbonyl compounds, esters, phenols, and all of their branched ones and geometric isomers can be calculated. Moreover, the proposed method can by introducing certain parameters accurately reproduce experimental values. A comparison of the results obtained by this method with those by conventional estimation methods is also presented.
\end{abstract}

\section{Introduction}

The critical properties and normal boiling points of pure substances are very important variables for the calculations of other physical properties in chemical process design. Thus, the procedures for estimation of critical constants have been reviewed by several authors for a wide variety of organic compounds. Some of the conventional methods(1) 3),6),8),12) employ group contribution models that necessitate information on molecular structure for estimating the critical properties of organic compounds containing oxygen. For accurate estimation of critical temperature, critical pressure, and normal boiling point, it is necessary to distinguish geometric isomers, i.e., branched alkyl side-chains and ortho-, meta-, and parasubstituents from each other. Most of the conventional group contribution methods include the normal boiling point as one of the variables for the estimation of critical temperature. For the estimation of critical pressure, Jalowka and Daubert have developed an equation that included both the normal boiling point and critical temperature as variables. In addition, a few normal boiling point models ${ }^{7},{ }^{10}$ ) have been developed for organic compounds containing oxygen.

In our previous studies ${ }^{4), 5)}$ we reported a method for estimating critical temperatures, critical pressures, and normal boiling points of hydrocarbons, i.e., alkanes, alkenes, alicyclic hydrocarbons, and

\footnotetext{
* To whom correspondence should be addressed.
}

aromatic hydrocarbons, by using their molecular weights and structures. In this study, the application of the estimation method is attempted to these organic compounds containing oxygen as a functional form consistent with their molecular weight and structure.

The experimental values of critical temperature, critical pressure, and normal boiling point of organic compounds containing oxygen are shown in Figs. 1 to 3. The values of those properties used in this work are obtained from the data base by Reid, Prausnitz, and Poling ${ }^{11)}$. The data base contains the following: experimental values of critical temperature of 23 alcohols, 15 ethers, and 13 phenols; those of critical pressure of 18 alcohols and 15 ethers; and those of normal boiling point of

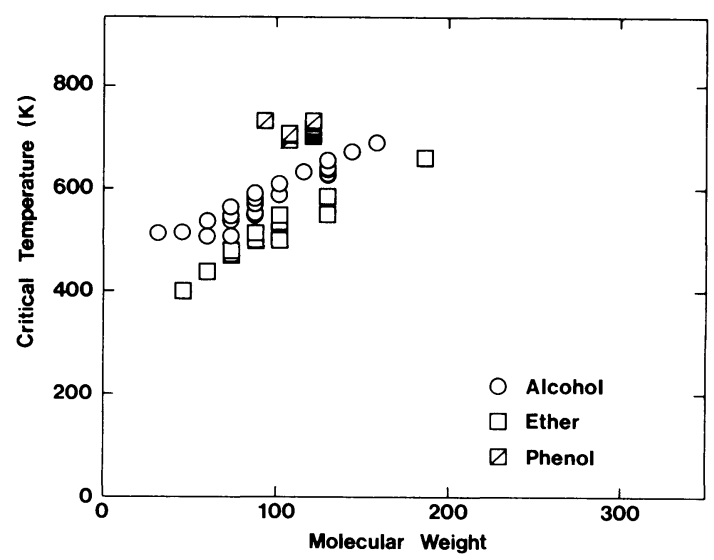

Fig. I Relationship between Critical Temperature and Molecular Weight 


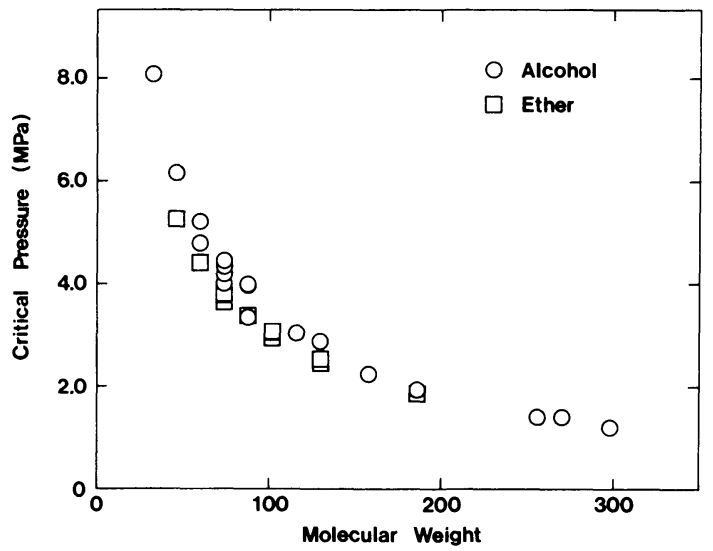

Fig. 2 Relationship between Critical Pressure and Molecular Weight

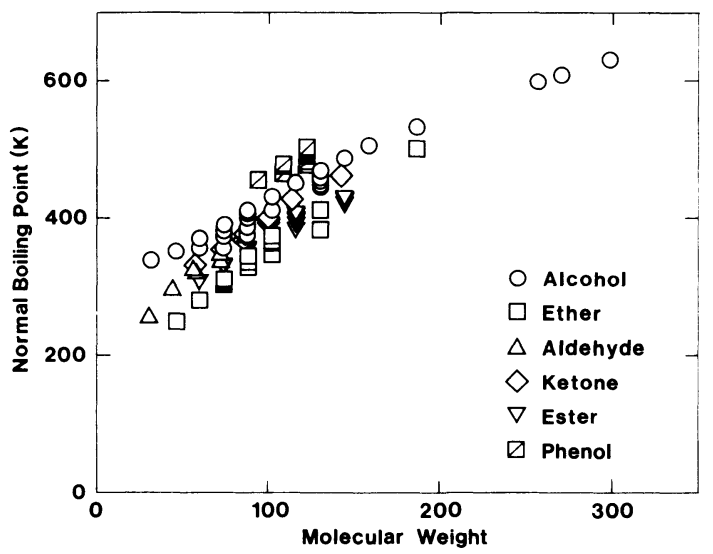

Fig. 3 Relationship between Normal Boiling Point and Molecular Weight

27 alcohols, 15 ethers, 7 aldehydes, 10 ketones, 24 esters, and 13 phenols. The values estimated in this work are compared with those estimated by conventional methods.

\section{Functional Form of Estimation Equation for Alcohols}

In the present estimation method for critical temperature, critical pressure, and normal boiling point, alcohols are classified into two types: 1alcohols and branched alcohols.

\subsection{1-Alcohols}

The values of critical temperature and pressure and normal boiling point of 1 -alcohols are calculated by using only molecular weight, $M$. The equation is developed in a manner similar to that for estimating these properties of $n$-alkanes4). The general functional form is given by Eq. (1).

$$
\begin{aligned}
Q_{1 \mathrm{a}}= & A+B / M^{0.8}+C \cdot(\ln M) / M^{0.8} \\
& +D \cdot(\ln M)^{1.5} / M^{0.8}+E \cdot(\ln M)^{2} / M^{0.8}
\end{aligned}
$$

Table l Constants of Eqs. (1), (3), (4), and (5)

\begin{tabular}{cccc}
\hline Constant & \multicolumn{1}{c}{$T_{\mathrm{c}}$} & \multicolumn{1}{c}{$P_{\mathrm{c}}$} & \multicolumn{1}{c}{$T_{\mathrm{b}}$} \\
\hline I-Alcohol & & & \\
$A$ & $1.2117 \times 10^{3}$ & 3.8384 & $1.3191 \times 10^{3}$ \\
$B$ & $1.1013 \times 10^{4}$ & $2.2372 \times 10^{3}$ & $-2.6666 \times 10^{4}$ \\
$C$ & $-6.1786 \times 10^{3}$ & $-3.5433 \times 10^{3}$ & $1.5226 \times 10^{4}$ \\
$D$ & $3.4483 \times 10^{3}$ & $2.5082 \times 10^{3}$ & $3.3871 \times 10^{3}$ \\
$E$ & $-1.9177 \times 10^{3}$ & $-5.0554 \times 10^{2}$ & $-5.3002 \times 10^{3}$ \\
Branched alcohol & & \\
$F$ & 4.7021 & $-8.7960 \times 10^{-1}$ & 5.5906 \\
$G$ & -2.6075 & $3.0717 \times 10^{-1}$ & -3.3844 \\
$H$ & $-1.8816 \times 10^{4}$ & $-5.1313 \times 10^{2}$ & $-1.6935 \times 10^{4}$ \\
\hline$T_{\mathrm{c}}:$ critical temperature, $P_{\mathrm{c}}:$ critical pressure, $T_{\mathrm{b}}:$ normal \\
boiling point.
\end{tabular}

where $Q_{1 \mathrm{a}}$ represents either the critical temperature, critical pressure, or normal boiling point of 1-alcohol. The values from $A$ to $E$ in Eq. (1) are constants and are determined by fitting the experimental values of critical temperature, critical pressure, and normal boiling point of 1 alcohols, where the following object function is minimized by Marquardt method ${ }^{9}$.

$$
F_{\text {obj. }}=\left\{Q_{\text {obsd. }}-Q_{\text {calcd. }}\right\}^{2}
$$

The constants obtained are shown in Table 1.

\section{2 Branched Alcohols}

In order to accurately estimate the critical temperature and pressure and normal boiling point, it is necessary for branched alcohols to identify and distinguish their geometric isomers from each other. Four structural parameters, $K_{2}, K_{3}, \gamma$, and $w$, are introduced, and are calculated from the structural formula of the molecule. $K_{2}$ and $K_{3}$ are the parameters denoting the number of pairs of carbon atoms two and three bonds apart, respectively (i.e. $\mathrm{C}-\mathrm{C}-\mathrm{C}$ of $K_{2}$ and $\mathrm{C}-\mathrm{C}-\mathrm{C}-\mathrm{C}$ of $K_{3}$ ). $\gamma$ is the parameter for subclassification of alcohols as primary, secondary, and tertiary. The values of $\gamma$ are: $\gamma=1$ for primary, $\gamma=2$ for secondary, and $\gamma=3$ for tertiary alcohols, respectively. In addition, the Wiener number, $w^{13}$, is introduced to distinguish between the isomers. In the original reports ${ }^{4}$, that number has been defined for alkanes. It is calculated by multiplying the number of carbon atoms on one side of each carbon-carbon bond by the number of carbons on the other side of the bond and adding all the contributions from each carbon-carbon bond in the structural formula. Therefore, the Wiener number is extended to the branched alcohols in this study. The estimation equation for critical temperature of branched alcohols, $T_{\mathrm{c}, \mathrm{ba}}$ is given by Eq. (3).

$$
\begin{aligned}
T_{\mathrm{c}, \mathrm{ba}}= & T_{\mathrm{c}, 1 \mathrm{a}}+F+G \cdot\left(K_{2}-K_{3}+\gamma\right) \\
& +H\left\{0.8 \cdot\left(K_{2}-K_{3}+\gamma\right)+\left(w_{1}-w_{\mathrm{B}}\right)\right\} / M^{2}
\end{aligned}
$$


The critical pressure and normal boiling point are

$$
\begin{aligned}
P_{\mathrm{c}, \mathrm{ba}}= & P_{\mathrm{c}, 1 \mathrm{a}}+F+G \cdot\left(K_{2}-K_{3}+\gamma\right) \\
& +H\left\{0.8 \cdot\left(K_{2}-K_{3}+\gamma\right)^{2}+\left(w_{1}-w_{\mathrm{B}}\right)\right\} / M^{1.7}
\end{aligned}
$$

$$
\begin{aligned}
T_{\mathrm{b}, \mathrm{ba}}= & T_{\mathrm{b}, 1 \mathrm{a}}+F+G \cdot\left(K_{2}-K_{3}+\gamma\right) \\
& +H \cdot\left(w_{1}-w_{\mathrm{B}}\right) / M^{2}
\end{aligned}
$$

where $T_{\mathrm{c}, 1 \mathrm{a}}, P_{\mathrm{c}, 1 \mathrm{a}}$ and $T_{\mathrm{b}, 1 \mathrm{a}}$ are calculated values of the corresponding 1-alcohols given by Eq. (1), $w_{1}$ and $w_{\mathrm{B}}$ are the Weiner number of 1 -alcohol and branched alcohols, and $F, G$, and $H$ are constants and are determined from the observed values. The constants in Eqs. (3) to (5) are shown in Table 1.

\section{Functional Form of Estimation Equation for Ethers}

Ethers are also classified into two types: methylalkylethers $\left(\mathrm{CH}_{3}-\mathrm{O}-\mathrm{C}_{n} \mathrm{H}_{2 n+1}\right)$ and other alkylethers $\left(\mathrm{C}_{n} \mathrm{H}_{2 n+1}-\mathrm{O}-\mathrm{C}_{n} \mathrm{H}_{2 n+1}\right)$.

Critical temperatures and pressures and normal boiling points of methylalkylethers are calculated by using only molecular weight, $M$. The general functional form is,

$$
Q_{\mathrm{mae}}=A+B / M+C \cdot(\ln M)^{2} / M
$$

where $Q_{\text {mae }}$ represents the critical temperature, critical pressure, or normal boiling point. $A, B$, and $C$ are the constants and are shown in Table 2 .

For alkylethers, except methylalkylether, the critical temperature, critical pressure, and normal boiling point can be expressed, using a certain structural parameter as,

$$
\begin{aligned}
Q_{\mathrm{ae}}= & Q_{\mathrm{mae}}+D+E \cdot\left(L_{\mathrm{cn}} \cdot R_{\mathrm{cn}}\right) / M \\
& +F \cdot\left(K_{1}+K_{2}+K_{3}+K_{4}\right) / M^{2}
\end{aligned}
$$

where $L_{\mathrm{cn}} \leqq R_{\mathrm{cn}}$

where $Q_{\mathrm{ae}}$ represents either the critical temperature, critical pressure, or normal boiling point; and

Table 2 Constants for Eqs. (6) and (7)

\begin{tabular}{cccc}
\hline \multirow{2}{*}{ Constant } & \multicolumn{3}{c}{$Q_{\mathrm{mae}}, Q_{\mathrm{ae}}$} \\
\cline { 2 - 4 } & $T_{\mathrm{c}}$ & \multicolumn{1}{c}{$P_{\mathrm{c}}$} & $T_{\mathrm{b}}$ \\
\hline$A$ & $1.0932 \times 10^{3}$ & $-2.7439 \times 10^{-1}$ & $8.3793 \times 10^{2}$ \\
$B$ & $2.0288 \times 10^{4}$ & $7.0866 \times 10^{3}$ & $1.7520 \times 10^{4}$ \\
$C$ & $-3.5592 \times 10^{3}$ & $1.2493 \times 10^{3}$ & $-3.0450 \times 10^{3}$ \\
$D$ & $1.1774 \times 10^{2}$ & $2.6431 \times 10^{-1}$ & $5.9076 \times 10$ \\
$E$ & $-3.3811 \times 10^{2}$ & $-8.9611 \times 10^{-1}$ & $3.5410 \times 10$ \\
$F$ & $-6.1925 \times 10^{4}$ & $-1.3958 \times 10^{2}$ & $-6.1099 \times 10^{4}$ \\
\hline
\end{tabular}

$D, E$, and $F$ are constants. $K_{1}, K_{2}, K_{3}$, and $K_{4}$ denote the number of pairs of carbon atoms one, two, three, and four bonds apart, respectively. $L_{\mathrm{cn}}$ and $R_{\mathrm{cn}}$ are defined as the number of carbon atoms on the left side of the ether group (-O-) bond and on the right side of the bond in the structural formula. The constants in Eq. (7) are also shown in Table 2.

\section{Equation for Estimating Normal Boiling Point of Carbonyl Compounds and Esters}

\section{1 Carbonyl Compounds}

The equation for estimating normal boiling points of carbonyl compounds (including aldehydes and ketones) was similarly derived as it was for ethers. The carbonyl compounds are also classified into two types: (1) alkylaldehydes $\left(\mathrm{C}_{n} \mathrm{H}_{2 n+1}-\mathrm{CO}-\mathrm{CHO}\right)$ and methylalkylketones $\left(\mathrm{CH}_{3}-\mathrm{CO}-\mathrm{C}_{n} \mathrm{H}_{2 n+1}\right)$ and (2) carbonyl compounds, except alkylaldehydes and methylalkylketones $\left(\mathrm{C}_{n} \mathrm{H}_{2 n} \mathrm{O}\right)$.

For alkylaldehydes and methylalkylketones, $T_{\mathrm{b}, \mathrm{cc} 1}$ is derived using only their molecular weights, as in Eq. (8).

$$
\begin{aligned}
T_{\mathrm{b}, \mathrm{cc} 1}= & -5.7533 \times 10^{3} \\
& +2.5177 \times 10^{3} \cdot(\ln M)^{0.5} \\
& +3.5347 \times 10^{3} \cdot(\ln M)^{2} / M
\end{aligned}
$$

For carbonyl compounds, except alkylaldehyde and methylalkylketones, the normal boiling point is calculated by using the number of carbon atoms included in the straight side-chain, $S_{\mathrm{c}}$. The estimation equation, $T_{\mathrm{b}, \mathrm{cc} 2}$ is given by Eq. (9):

$$
\begin{aligned}
T_{\mathrm{b}, \mathrm{cc} 2}= & T_{\mathrm{b}, \mathrm{cc} 1}+2.6045-1.0617 \times 10^{3} \cdot S_{\mathrm{c}} / M \\
& -4.7700 \times 10 \cdot\left(L_{\mathrm{cn}} \cdot R_{\mathrm{cn}}\right) / M
\end{aligned}
$$

where $L_{\mathrm{cn}}$ is the number of carbon atoms on the left side of ketone group (-CO-) bond and $R_{\mathrm{c}}$ on the right side of the bond in the structural formula.

\section{2 Esters}

Esters are also classified into three structural types: (1) esters of formic acid composed of straight-chains (HCOO- $\mathrm{C}_{n} \mathrm{H}_{2 n+1}$ ), (2) acetic esters composed of straight-chains $\left(\mathrm{CH}_{3}-\mathrm{COO}-\mathrm{C}_{n} \mathrm{H}_{2 n+1}\right)$, and (3) other esters. The estimation equation for both esters of formic acid composed of straightchains, and acetic esters composed of straightchains has the same functional form using only their molecular weights.

For esters of formic acid composed of straightchains, the normal boiling point, $T_{\mathrm{b}, \mathrm{es} 1}$, can be expressed by Eq. (10). 


$$
\begin{aligned}
T_{\mathrm{b}, \mathrm{es} 1}= & 6.5200 \times 10^{2}+2.4116 \times 10^{3} \cdot(\ln M) \\
& -8.1943 \times 10^{2} \cdot(\ln M)^{3 / M}
\end{aligned}
$$

The estimation equation of acetic esters composed of straight-chains, $T_{\mathrm{b}, \mathrm{es} 2}$, is given by Eq. (11)

$$
\begin{aligned}
T_{\mathrm{b}, \mathrm{es} 2}= & 3.1317 \times 10^{2}+6.6506 \times 10^{3} \cdot(\ln M) \\
& -1.4189 \times 10^{3} \cdot(\ln M)^{3 / M}
\end{aligned}
$$

For esters, except for those of formic acid and acetic esters composed of straight-chains, in order to distinguish the geometric isomers from each other, four structural parameters, $K_{1}, K_{2}, L_{\mathrm{cn}}$, and $R_{\text {cn }}$ were replaced by ester group (-COO-). The normal boiling point of those esters, $T_{\mathrm{b}, \mathrm{es}}$, given by Eq. (12)

$$
\begin{aligned}
T_{\mathrm{b}, \mathrm{es} 3}= & T_{\mathrm{b}, \mathrm{es} 2}-1.1998 \times 10 \\
& +8.3568 \times 10 /\left(2 \cdot L_{\mathrm{cn}}+R_{\mathrm{cn}}\right) \\
& -2.8255 \times 10^{2} \cdot\left(K_{1}-K_{2}\right)^{2} / M
\end{aligned}
$$

\section{Functional Form of Estimation Equation for Phenols}

For phenols, both the critical temperature and normal boiling point have the same functional form and it can be expressed by using four structural parameters, $O C, M C, C N_{\mathrm{OP}}$, and $C N_{\mathrm{MP}} . \quad O C$ and $M C$ are the number of pairs of carbon atom at ortho-position and at meta-position, respectively. $C N_{\mathrm{OP}}$ and $C N_{\mathrm{MP}}$ are the number of carbon atom at ortho-position with a hydroxyl group and at metaposition, respectively. For instance, in 2,3xylenol, $O C=1, M C=1, C N_{\mathrm{OP}}=1$, and $C N_{\mathrm{MP}}=0$. A general form, Eq. (13), is employed.

Table 3 Constants for Eq. (12)

\begin{tabular}{clc}
\hline \multirow{2}{*}{ Constant } & \multicolumn{2}{c}{$Q_{\mathrm{p}}$} \\
\cline { 2 - 3 } & \multicolumn{1}{c}{$T_{\mathrm{c}}$} & \multicolumn{1}{c}{$T_{\mathrm{b}}$} \\
\hline$A$ & $6.2274 \times 10^{2}$ & $3.4556 \times 10^{2}$ \\
$B$ & $8.3868 \times 10^{2}$ & $6.4355 \times 10^{2}$ \\
$C$ & $9.6408 \times 10^{-1}$ & $2.3740 \times 10^{2}$ \\
$D$ & $7.5993 \times 10^{-1}$ & 1.1717 \\
\hline
\end{tabular}

$$
\begin{aligned}
Q_{\mathrm{p}}= & A+B \cdot\left(2 \cdot O C-C N_{\mathrm{OP}}\right) / M \\
& +C \cdot\left(C N_{\mathrm{MP}}-M C\right) / M+D \cdot M
\end{aligned}
$$

where $Q_{\mathrm{p}}$ represents the critical temperature or the normal boiling point of phenols, and $A, B, C$, and $D$ are constants. Both sets of constants in Eq. (12) are shown in Table 3.

\section{Comparison of Results}

Critical temperatures of 51 organic oxygen compounds, critical pressures of 38 , and normal boiling points of 96 involving alcohols, ethers, carbonyl compounds, esters, and phenols were calculated. The results obtained with the method developed in this work are compared with those obtained with the conventional methods.

For alcohols, the average and maximum absolute deviations between the experimental and calculated values are shown in Table 4 . This table shows the same deviations calculated by using some of the conventional estimation methods. For critical temperatures of alcohols, the present method gives an average absolute deviation of $2.1 \mathrm{~K}$ and a maximum absolute deviation of $7.2 \mathrm{~K}$. For critical pressure, the average absolute deviation is $0.049 \mathrm{MPa}$ and the maximum absolute deviation $0.163 \mathrm{MPa}$. For normal boiling point, the average absolute deviation is $1.6 \mathrm{~K}$ and the maximum absolute deviation of $5.6 \mathrm{~K}$. Estimations by Eqs. (1), (3), (4), and (5) can reproduce experimental values more accurately than can any conventional method.

A comparison of the estimated results available for ethers are shown in Table 5. The average and maximum absolute deviations for critical temperatures of ethers are $2.2 \mathrm{~K}$ and $9.2 \mathrm{~K}$, respectively. For critical pressure, the average

\begin{tabular}{|c|c|c|c|c|c|c|c|}
\hline \multirow[t]{2}{*}{ Author } & \multicolumn{2}{|c|}{$T_{\mathrm{c}}[\mathrm{K}]$} & \multicolumn{2}{|c|}{$\begin{array}{c}\text { Deviation } \\
P_{\mathrm{c}}[\mathrm{MPa}]\end{array}$} & \multicolumn{2}{|c|}{$T_{\mathrm{b}}[\mathrm{K}]$} & \multirow[t]{2}{*}{ Lit. } \\
\hline & AAD & MAD & AAD & MAD & AAD & MAD & \\
\hline This work & 2.1 & 7.2 & 0.049 & 0.163 & 1.6 & 5.6 & \\
\hline Somayajulu (1989) & 2.1 & 8.3 & 0.102 & 0.567 & - & - & 12 \\
\hline Lai, Chen, and Maddox (1987) & - & - & - & - & 4.4 & 25.4 & 7 \\
\hline Klincewicz and Reid (1984) & 7.6 & 17.0 & - & - & - & - & 6 \\
\hline Fedors (1979) & 15.3 & 46.9 & - & - & - & - & 3 \\
\hline Ambrose (1974) & 3.5 & 17.2 & 0.172 & 0.559 & - & - & 1 \\
\hline Lydersen (1955) & 14.7 & 31.3 & 0.209 & 0.681 & - & - & 8 \\
\hline
\end{tabular}
and maximum absolute deviations are $0.035 \mathrm{MPa}$ and $0.128 \mathrm{MPa}$, respectively. For normal boiling point, the average and maximum absolute deviations are $1.6 \mathrm{~K}$ and $4.2 \mathrm{~K}$, respectively. The results obtained from Eqs. (6) and (7) are found to be more accurate than those obtained from any

Table 4 Comparison of Estimation Results of Critical Temperature, Critical Pressure, and Normal Boiling Point between This Study and Conventional Methods for Alcohols

AAD (average absolute deviation $)=\left(\sum^{N} \mid(\right.$ calcd $)-($ obsd $\left.) \mid\right) / N, N=$ number of data. MAD=maximum absolute deviation 
Table 5 Comparison of Estimation Results of Critical Temperature, Critical Pressure, and Normal Boiling Point between This Study and Conventional Methods for Ethers

\begin{tabular}{|c|c|c|c|c|c|c|c|}
\hline \multirow[t]{2}{*}{ Author } & \multicolumn{2}{|c|}{$T_{\mathrm{c}}[\mathrm{K}]$} & \multicolumn{2}{|c|}{$\begin{array}{l}\text { Deviation } \\
P_{\mathrm{c}}[\mathrm{MPa}]\end{array}$} & \multicolumn{2}{|c|}{$T_{\mathrm{b}}[\mathrm{K}]$} & \multirow[t]{2}{*}{ Lit } \\
\hline & AAD & MAD & $\mathrm{AAD}$ & MAD & AAD & MAD & \\
\hline This work & 2.2 & 9.2 & 0.035 & 0.128 & 1.6 & 4.2 & \\
\hline Daubert et al. (1989) & 5.2 & 30.0 & 0.068 & 0.200 & - & - & 2 \\
\hline Somayajulu (1989) & 2.0 & 8.1 & 0.074 & 0.151 & - & - & 12 \\
\hline Lai, Chen, and Maddox (1987) & - & - & - & - & 6.8 & 42.6 & 7 \\
\hline Klincewicz and Reid (1984) & 4.2 & 23.4 & - & - & - & - & 6 \\
\hline Fedors (1979) & 10.8 & 25.7 & - & - & - & - & 3 \\
\hline Purarelli (1976) & - & - & - & - & 9.3 & 36.9 & 10 \\
\hline Ambrose (1974) & 2.3 & 7.2 & 0.070 & 0.159 & - & - & 1 \\
\hline Lydersen (1955) & 2.3 & 5.9 & 0.064 & 0.232 & - & - & 8 \\
\hline
\end{tabular}

Table 6 Comparison of Estimation Results of Normal Boiling Point between This Study and Conventional Methods for Carbonyl Compounds and Esters

\begin{tabular}{|c|c|c|c|c|c|}
\hline \multirow[t]{2}{*}{ Author } & \multicolumn{2}{|c|}{$\begin{array}{c}\text { Carbonyl compound } \\
T_{\mathrm{b}}[\mathrm{K}]\end{array}$} & \multicolumn{2}{|c|}{$\begin{array}{c}\text { Ester } \\
T_{\mathrm{b}}[\mathrm{K}]\end{array}$} & \multirow[t]{2}{*}{ Lit } \\
\hline & $\mathrm{AAD}$ & MAD & AAD & MAD & \\
\hline This work & 1.9 & 4.3 & 1.4 & 4.1 & \\
\hline Lai, Chen, and Maddox (1987) & 5.5 & 11.3 & 6.9 & 16.0 & 7 \\
\hline Purarelli (1976) & 7.3 & 17.0 & 18.4 & 39.8 & 10 \\
\hline
\end{tabular}

Table 7 Comparison of Estimation Results of Critical Temperature and Normal Boiling Point between This Study and Conventional Methods for Phenols

\begin{tabular}{|c|c|c|c|c|c|}
\hline \multirow{3}{*}{ Author } & \multicolumn{4}{|c|}{ Deviation } & \multirow{3}{*}{ Lit. } \\
\hline & \multicolumn{2}{|c|}{$T_{\mathrm{c}}[\mathrm{K}]$} & \multicolumn{2}{|c|}{$T_{\mathrm{b}}[\mathrm{K}]$} & \\
\hline & AAD & MAD & AAD & MAD & \\
\hline This work & 0.7 & 2.6 & 1.9 & 3.9 & \\
\hline Somayajulu (1989) & 1.4 & 4.3 & - & - & 12 \\
\hline Klincewicz and Reid (1984) & 14.6 & 22.6 & - & - & 6 \\
\hline Fedors (1979) & 23.5 & 51.4 & - & - & 3 \\
\hline Purarelli (1976) & - & - & 49.7 & 64.6 & 10 \\
\hline Ambrose (1974) & 1.3 & 4.2 & - & - & 1 \\
\hline Lydersen (1955) & 4.8 & 11.9 & - & - & 8 \\
\hline
\end{tabular}

conventional method.

For carbonyl compounds and esters, the average and maximum absolute deviations between experimental and calculated values are shown in Table 6. For normal boiling point of carbonyl compounds, the present method gives the average absolute deviation of $1.9 \mathrm{~K}$ and the maximum absolute deviation of $4.3 \mathrm{~K}$. For esters, the average absolute deviation is $1.4 \mathrm{~K}$ and the maximum absolute deviation is $4.1 \mathrm{~K}$. Table 7 shows the results estimated for phenols. The table also includes the deviations calculated by conventional estimation methods. The results of estimation from Eqs. (8) to (13) are found to be most accurate.

\section{Nomenclatures}

$A, B, C, D, E, F$ : constants in Eqs. from (1) to (13)

$C N_{\mathrm{OP}} \quad$ : number of carbon atoms at ortho-position with group for phenol

$C N_{\mathrm{MP}} \quad$ : number of carbon atoms at meta-position with hydroxyl group for phenol
$K_{1}, K_{2}, K_{3}, K_{4} \quad$ : number of pairs of carbon atoms 1, 2, 3, or 4 bond apart

$L_{\mathrm{cn}} \quad$ : number of carbon atoms on the left side of ketone, or ester group bond

$\begin{array}{ll}M & \text { : molecular weight } \\ M C & \text { : number of pairs of carbon atom at meta- }\end{array}$ position

$O C$ : number of pairs of carbon atom at orthoposition

$P_{\mathrm{c}} \quad$ : critical pressure

$R_{\text {cn }} \quad$ : number of carbon atoms on the left side of ether, ketone, or ester group

$S_{\mathrm{c}} \quad$ : number of carbons including straight alkyl side-chain

: normal boiling point

: critical temperature

: the Wiener number of branched alcohol : parameter of subclassifications of alcohols as primary, secondary, or tertiary

\section{References}

1) Ambrose, D., Broderick, B. E., Townsend, R., J. Appl. Chem. Biotechnol., 24, 359 (1974).

2) Daubert, T. E., Bartakovutz, R., Ind. Eng. Chem. Res., 28, 
638 (1989)

3) Fedors, R. F., Chem. Eng. Comm., 16, 149 (1982).

4) Hiaki, T., Anazawa, I., Kojima, K., Sekiyu Gakkaishi, 33, (4), 208 (1990).

5) Hiaki, T., Takamori, S., Anazawa, I., Sekiyu Gakkaishi, 34, (4), 308 (1991).

6) Klincewicz, K. M., Reid, R. C., AIChE J., 30, 137 (1984).

7) Lai, W. Y., Chen, D. H., Maddox, R. N., Ind. Eng. Chem. Res., 26, 1072 (1987).

8) Lydersen, A. L., Univ. of Wisconsin, Eng. Exp. Sta. Rep.,
Madison (1955).

9) Marquardt, D. W., J. Soc. Indust. Appl. Math., 11, 431 (1963).

10) Purarelli, C., Chem. Eng., 30, 127 (1976).

11) Reid, R. C., Prausnitz, J. M., Poling, B. E., "The Properties of Gases and Liquids, fourth edition", McGraw-Hill, New York (1987).

12) Somayajulu, G. R., J. Chem. Eng. Data, 34, 106 (1989).

13) Wiener, H., J. Am. Chem. Soc., 69, 17 (1947). 


\title{
酸素を含む有機化合物の臨界温度，臨界圧力ならびに標準沸点の推算
}

\author{
日秋俊彦 ${ }^{\dagger 1)}$, 高森清次 ${ }^{\dagger 2}$ \\ 十1) 日本大学生産工学部工業化学科, 275 千葉県習志野市泉町 1-2-1 \\ †2)（株）日本製鋼所 研究開発本部中央研究所，284 千葉県四街道市鷹の台 1-3
}

純物質の臨界物性や標準沸点は, 化学プロセス設計に必要な 種々の物性計算に不可欠である。したがって，名種有機化合物 を対象とした物性推算法が提案されており，このうち酸素を含 む有機化令物を対象とした既往の臨界物性推算法(1) -3),6),8), 12) や標準沸点推算法7),10) の主流はグループ寄与法である。

本研究で推算式の検討の対象とした臨界温度, 臨界圧力およ び標準沸点の測定值を分子量に対してプロットしたのが,

Figs. 1 3 である。酸素を含む有機化合物の正確な推算には， アルキル側鎖の枝別れ， $o-, m-, p$ - 置換体などの異性体などを 区別する必要がある。既往の臨界温度推算法ではこれらをグ ループパラメーターと標準沸点を用いて区別するものが多く， 臨界圧力では Jalowka と Darbert が式中に臨界温度と標準沸 点の両方を用いている。また，標準沸点の推算法には有機化合 物を正確に計算できる方法は少ない。

著者らは先に，物質の分子量と化学構造のみに基づいてアル カン, アルケン, 脂肪族炭化水素および芳香族炭化水素の臨界 温度, 臨界圧力および標準沸点の推算法を示した ${ }^{4), 5)}$ 。本研究 は同様の方法を拡張し，酸素を含む有機化合物，すなわちアル コール，エーテル，カルボニル化合物，エステルおよびフェ ノールの臨界温度, 臨界圧力, および標準沸点の推算法を示 し，既往の方法による推算結果と比較検討したものである。な お，本研究で用いた臨界温度，臨界圧力ならびに標準沸点の実

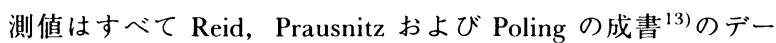
タベースを使用した。

アルコールの臨界温度, 臨界圧力および標準沸点の推算式は 1-アルコールと枝分かれ構造のアルコールとに分類し，1-アル コールは $n$-アルカンの推算式年文同時の分子量のみからなる Eq. (1)を採用した。なお，各実測值に基づく推算式の定数決 定には Marquardt 法を用い，目的関数は Eq. (2)とした。次 に，枝分かれ構造のアルコールは化学構造式から計算する構造 パロメーターを含む式を採用し Eq. (3)〜Eq.(5) とした。実測 值に基づいて決定したアルコールの各物性推算式の定数は
Table 1 に示す。

エーテルについては 2 種のタイプに分類し、メチルアルキ ルエーテルには各物性とも同型式で分子量のみを用いた Eq (6)，これを除くアルキルエーテルには分子量と構造より計算 するパラメーターを用いた Eq. (7) を採用した。測定值より沈 定した定数は Table 2 に示す。

アルデヒドおよびケトンを含むカルボニル化命物ならびに工 ステルの標準沸点の推算式は, カルボニル化合物がその構造か ら 2 種のタイプ, またエステルでは 3 種のタイプに分類し, Eqs. (8)〜 (12) とした。

フェノールの臨界温度および標準沸点の推算式は，共に同型 式で分子量と構造パラメーターを用いた Eq. (13)を採用し た。測定値より決定した定数は Table 3 に示す。

各物性の式中の定数決定には 51 種の臨界温度デー夕，38 種 の臨界圧力データならびに 96 種の標準沸点データを用いた。 本研究による計算結果は既往の推算法による計算結果とともに

Tables 4７に示した。これより，本方法によるアルコールの 臨界温度の計算値と実測値との絶対算術平均偏差は $2.1 \mathrm{~K}$, 最 大偏差は $7.2 \mathrm{~K}$, 同様に求めた臨界压力および標準沸点につい ての偏差はそれぞれ $0.049 \mathrm{MPa}, 0.163 \mathrm{MPa}$ ，および $1.6 \mathrm{~K}$, $5.6 \mathrm{~K}$ であった。次に，エーテルでは臨界温度の絶対算術平均 偏差が $2.2 \mathrm{~K}$, 最大偏差は $9.2 \mathrm{~K}$, 臨界圧力および標準沸点に ついての偏差はそれぞれ $0.035 \mathrm{MPa}, 0.128 \mathrm{MPa}$ ，および 1.6 $\mathrm{K}, 4.2 \mathrm{~K}$ であった。また, カルボン酸の標準沸点の計算值と 実測値との絶対算術平均偏差および最大偏差はそれぞれ 1.9 $\mathrm{K}, 4.3 \mathrm{~K}$, エステルの標準沸点は $1.4 \mathrm{~K}, 4.1 \mathrm{~K}$ 。フノール の臨界温度ならびに標準沸点の絶対算術平均偏差および最大偏

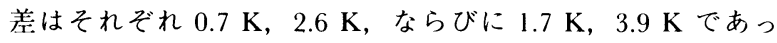
た。

本研究の推算式による結果は, 既往の推算法による結果と比 較して異性体を含む広い範囲で最も良好に一致した。

\section{Keywords}

Estimation equation, Critical temperature, Critical pressure, Normal boiling point, Organic oxygen compound 